\title{
Soils Acidity Characterization, Mapping and Lime Recommendation of Jimma Arjo District, East Wollega Zone of Oromia Region, Ethiopia
}

Fayisa Olana Bulo ( $\nabla$ fayisa.bulo@gmail.com )

International Fertilizer Development Center https://orcid.org/0000-0001-8718-5826

Hailu Shiferaw Desta

Addis Ababa University

\section{Research}

Keywords: Acid Saturation, Ag-lime, East Wollega, EthioSIS, Soil Acidity

Posted Date: July 7th, 2021

DOl: https://doi.org/10.21203/rs.3.rs-637000/v1

License: (c) (i) This work is licensed under a Creative Commons Attribution 4.0 International License.

Read Full License 


\section{Abstract}

Background: Soil fertility is one of the major constraints of agricultural production and productivity. Soil fertility atlas shows plant nutrient status and is useful for decision making in fertilizers and other amendments advisory service for farmers. The objectives of this research were to study the farming activity, assess the acidity status of the soils, map and recommend the right amount of lime for acidic soils.

Result: A total of 199 soil samples were collected across Jimma Arjo district at $1.5 \mathrm{~km}$ grid interval from a depth of $0-20 \mathrm{~cm}$ for annual and $0-50 \mathrm{~cm}$ for perennial crops. The total area of the district was 76,574 ha. Soil reaction $(\mathrm{pH})$, electrical conductivity $(\mathrm{EC})$ and exchangeable acidity (EA) were done at Nekemte Soil Research Center. Exchangeable bases $(\mathrm{Ca}, \mathrm{Mg}, \mathrm{K}, \mathrm{Na})$ were analyzed by wet chemistry analysis at Yara Analytical Services, England. Critical levels adopted by the Ethiopian Soil Information System (EthioSIS) project were used for characterization of the soil properties. Soil reaction $(\mathrm{pH})$ ranged from 4.45 to 6.87 in which 17.1 and $78.4 \%$ of the total area was covered by strongly acidic soils and slightly acidic soils, respectively. Agricultural lime (Ag-lime) was required for $17.87 \%$ of the total area and $12.63 \%$, $4.36 \%$ and $0.88 \%$ of the total area require lime at a rate of $0-1,1-2$, and $2-4.1$ tons/ha respectively.

Conclusion: The highland areas of the district are more populated and there is high pressure on soil, cooler temperature and higher rainfall than lowlands which resulted in soil acidity of the highlands. The magnitude and extent of soil acidity in the area is expanding and liming is very important as an entry point to mitigate further expansion. The observed dependency of the soil acidity on landscape position could be a proxy indicator of the difference in fertility status of the two landscapes.

\section{Background}

Agriculture plays an important role in Ethiopia's political, economic, and social development. It forms one of the largest components of the Ethiopian economy, contributing over 35\% of the Country's gross domestic product (GDP), $66 \%$ of employment and over $76 \%$ of total export earnings (NBE Annual Report 2017-2018). Crop production makes up $72 \%$ of the total agricultural GDP, whereas livestock accounts for $20 \%$ and other areas contribute $8.6 \%$. Cereals (such as wheat, maize, tef, sorghum, and millet), comprise the biggest share of crop production as principal staples. In the 2019/20 season alone 33.52 million tons of grains were produced by smallholder farmers in Ethiopia and 1.16 mil ton in East Wollega Zone (CSA, 2019/20). In addition, vegetables, fruits, root crops, pulses, oilseeds, and spices are grown widely. With a total area of about 113 million hectares (ha) and about 36 million ha of arable land, the country has tremendous potential for agricultural development. However, only about 12.86 million ha of land, just over 35 per cent of the total arable area is currently being cultivated (CSA, 2019/20).

The average productions of cereals, pulses and oil crops are $2.83,1.92$ and 1.03 tons per hectare, respectively (CSA, 2019/20). Over the past decade, cereal production has more than doubled and increased by $6.21 \%$ over the last season because of horizontal expansion, increased yields and improved 
soil management (CSA, 2019/20). There is consistent upward trajectory for key staple crops over the last year (2018/19), resulting a national average productivity increment of $5.68 \%$ for maize, $5.33 \%$ for tef, $7.3 \%$ for wheat, and $14.87 \%$ for barley (CSA, 2019/20). Nevertheless, food security remains a critical issue for many households, and for the country as a whole. For example, 5.6 million people in Ethiopia in 2017 were categorized under crisis requiring severe humanitarian assistance (WFP, 2017).

One of the main constraints for food insecurity is low level of agricultural production and productivity, which in turn affected by low soil fertility and soil degradation. The main cause of soil fertility degradation in Ethiopia is human activity through cultivating sloppy areas without soil conservation methods and poor soil cover (Kassaye Gurebiyaw and Abay Gelanew, 2019). Soil degradation in the Eastern African highlands is mainly due to soil erosion, gully formation, soil fertility loss, which results in reductions in crop yield (Meseret, 2016). Among others, nutrient deficiencies, sub-optimum management, and availability of limited information on soil nutrient contents are factors constraining yields (Hengl et al., 2017). Crop response to application of fertilizers is mainly governed by the characteristics and topographic sequence of landscapes (Amede et al., 2020b), whereby crop response to inputs is significantly higher in valley bottoms and flatlands compared to hill slopes and degraded uplands (Amede et al., 2020b; Getnet et al., 2020). Therefore, in order to achieve optimum agronomic efficiency of inputs, fertility status of the soils need to be known.

Soil fertility assessment indicates the plant nutrient status which is useful for decision making on fertilizer advisory services including fertilization and liming. Despite the application of high rates of fertilizers, marginal soils produce low yields compared to moderately fertile soils (Vanlauwe et al., 2015; Agegnehu and Amede, 2017). Soil chemical, physical and biological properties can vary extensively within fields. Therefore, characterizing and mapping the fertility status of agricultural fields by district level is important for decision making on sources and rates of fertilizers and soil amendment materials.

Jimma Arjo is one of the rural districts of Ethiopia that inherited the physical and economic situations prevailing in the country due to declining soil fertility and increasing soil acidity. Some farmlands were abandoned due to soil degradation and acidity (Mulata, 2009). It is located in high rainfall receiving area where there were leaching of nutrients and topsoil removal which caused nutrient loss and aggravate soil acidity. Most areas of the district were covered with Nitisol (MoA, 2005). This soil has good workability, good internal drainage and fair water holding capacity; these are complemented by chemical fertility properties, and being susceptible for soil acidity problem. Therefore, assessing and maintaining the chemical fertility of the soils of the district is very important to obtain optimum and sustainable crop production. The objectives of this research were to understand farming practices of smallholder farmers, assess and map the acidity status of the soil, identify and recommend the right sources and rates of agricultural lime for acidic soils reclamation of the soils in the Jimma Arjo district.

\section{Materials And Methods}


The study was conducted in Jimma Arjo district that is located between $8^{\circ} 32^{\prime} 39^{\prime \prime}$ to $8^{\circ} 55^{\prime} 10^{\prime \prime} \mathrm{N}$ latitude and $36^{\circ} 22^{\prime} 17^{\prime \prime}$ to $36^{\circ} 43^{\prime} 53^{\prime \prime} E$ longitude in East Wollega Zone of the Oromia National Regional State, Ethiopia. Arjo town, which is the capital of the district, is situated at about $378 \mathrm{~km}$ distance from Addis Ababa city in western direction (Fig. 1). The total area of the district was estimated to be $765.74 \mathrm{~km}^{2}$ or 76,574 ha with a total population of 86,329 . The non-agricultural land of the district constitutes 3415.25 ha.

The elevation of the study area ranges from $1280.67 \mathrm{~m}$ to $2563.77 \mathrm{~m}$ above sea level. Some area of the southern part of the district is owned by Arjo Didesa Sugar Factory and is entirely being used for irrigated sugarcane (Saccharum officinarum L.) production. South Western part of the area is occupied by investors and is entirely used for rain-fed agriculture mainly for maize (Zea mays) production. The remaining agricultural land is occupied by local small holder farmers who practice mixed agriculture. During the field study the district, especially the highland is under intensive cultivation and tef (Eragrostis tef Zucc.), maize (Zea mays), bread wheat (Triticum aestivum L.), sorghum (Sorghum bicolor), barley (Hordeum vulgare L.), niger seed (Guizotia abyssinica), sesame, beans, and peas were the major crops grown.

The recent eleven years meteorological data of the nearby station at Jimma Arjo shows that the mean annual minimum and maximum temperatures of the district are 11.72 and $22.09^{\circ} \mathrm{C}$ respectively, and the mean annual rainfall is $2417 \mathrm{~mm}$ (Fig. 2). The area has a unimodal rainfall pattern and the highest rainfall is recorded in the month of July. The district falls in between the traditional wet Kolla and wet Dega agro-climatic zones. From the total area of the district, $4.5 \%$ falls in Wet Kolla which is hot to warm moist lowland (Tropical), $80.7 \%$ is Wet Weyna Dega which is tepid to cool moist mid highlands (subtropical) and 15\% falls in Wet Dega (temperate) climates (Mulata, 2009).

According to the extracted digital soil data obtained from MoA (2005), the area has 4 major soil orders based on FAO/UNESCO soil classification system. They are Dystric Nitisols, Pellic Vertisols, Dystric Gleysols and Orthic Acrisols (Fig. 3). A survey of the land in this district shows that $59.8 \%$ is arable, $9.6 \%$ pasture, $8.4 \%$ forest, and the remaining $22.2 \%$ is considered swampy, mountainous, or otherwise unusable.

\subsection{Site selection and soil sampling}

The tentative sampling points were distributed at $1.5 \mathrm{~km}$ grid intervals throughout the district using QGIS version 3.8 and the area of interest for soil sampling was prepared to establish the pre-defined sampling points (Fig. 4). The region of interest for soil sampling location was prepared by stratifying the agricultural land and non- agricultural land from the country's land use/land cover map. To develop the agricultural map to be used as a background for this survey, different data sets such as Woody Biomass 2000, Central Statistical Agency-Land Cover Classification Survey project and AfSIS-EthioSIS-land use/land cover map were reviewed. To validate this map, ground truthing from EthioSIS confluence point and nhaco nno dictrint cnil curvav data wora utilized. Under the context of this research, agricultural land Loading [MathJax]/jax/output/CommonHTML/jax.js 
includes land covers such as low land shrub, low land open woodland, grassland, fallow land, and principally currently cultivated land. The tentative sampling points that fall out of agricultural land were excluded and the predefined sampling points that fall on agricultural land were surveyed.

Surface $(0-20 \mathrm{~cm})$ soil samples were collected during the off season using systematic sampling technique. An Edelman soil auger marked at 20 and $50 \mathrm{~cm}$ length was used to collect the soil samples. At the plot level, basic site characteristics were described and recorded using smart tablet and standard description sheet. Android tablet was used to navigate the sampling points and to record all field data. After locating the centre of sampling point by global positioning system from the smart tablet, soil samples were taken one from the centre and the other eight surrounding the centre at a radius of $15 \mathrm{~m}$ by using auger to the depth of $20 \mathrm{~cm}$ for annual crops and $50 \mathrm{~cm}$ for perennial crops. The sub-samples taken from each subplot were pooled into one bucket and thoroughly mixed and homogenized after which a representative sample of approximately $1.0 \mathrm{~kg}$ was taken and placed in a properly labelled sample bag to represent one composite sample and transported to the laboratory. A total of 199 composite soil samples were collected during off season of 2016 from agricultural land of the entire district (Fig. 4). Finally, a clinometer (SUNTO) was used to measure slope in percent and fertilizer use history was gathered from key informants of the localities.

\subsection{Soil sample preparation and analysis}

Soil samples preparation was conducted at Nekemte Soil Research Center, Nekemte, Oromia, Ethiopia. The samples were air dried and crushed using mortar and pestle and sieved through a $2 \mathrm{~mm}$ mesh sieve. Few of the basic wet chemistry analysis was done at Nekemte Soil Research Center. For example, soil pH was analysed by $\mathrm{pH}$-meter from 2:1 water soil ratio and exchangeable $\mathrm{H}^{+}$and $\mathrm{Al}^{+++}$was determined by $\mathrm{KCl}$ extraction method in $\mathrm{cmol}_{+} / \mathrm{kg}$ at Nekemte Soil Research Center. Whereas, the laboratory analysis of basic cations $\left(\mathrm{Ca}^{++}, \mathrm{Mg}^{++}, \mathrm{Na}^{+}\right.$and $\left.\mathrm{K}^{+}\right)$in $\mathrm{Cmol}_{+} / \mathrm{kg}$ were conducted following Mehlich-III extraction method at Yara Analytical Services, England.

\subsection{Soil data analysis}

Soil characteristics data analysis by Principal Component Analysis (PCA) was carried out using XLSTAT software version 2015, which is the commonly used multivariate method which gives an interpretable overview of the main information in a multidimensional data table. The information carried by the original variables is projected onto a smaller number of underlying or latent variables called principal components (PC). The first PC covers as much of the variables in the data as possible. The second PC is orthogonal to the first and covers as much of the remaining variation as possible, and so on. By plotting the PC, one can view interrelationships between different variables, and detect and interpret sample patterns, groupings, similarities or differences. It helps to find out if the changes in soil properties in some observations (soil samples) are very different from the ones in other observations. In addition, different statistical parameters and comparisons were done by using the same software.

\subsection{Soil property and nutrient prediction}


The digital soil properties maps of the study area were prepared by developing statistical models using field data, and laboratory results. These include sampling point's coordinates and the corresponding laboratory values at all points for a parameter to be predicted. These parameters explain the soil properties and soil spatial relationship of the area on which the model depends. Each soil nutrient was interpolated across the study area using geo-statistical model. Ordinary kriging that is capable of handling larger number of samples and prediction points was used to develop an interpolation model. To predict unknown value at unsampled point $S_{0}$, the nearest 12 known values were used. The basic equation to predict the values according to ordinary kriging is given by Eq. 1 (Eq. 1):

$\check{Z}\left(\mathrm{~S}_{0}\right)=\sum_{i=1}^{n} \lambda i \mathrm{Z}(\mathrm{S} i)$ Eq. 1

Where $\check{Z}\left(\mathrm{~S}_{0}\right)$ is the predicted value at unsampled location, $\mathrm{n}$ is the number of known values located nearest to the unsampled location, $\lambda i$ is an unknown weight for the measured value at the $i^{\text {th }}$ location, $\mathrm{Z}\left(\mathrm{S}_{\mathrm{i}}\right)$ is the measured value at the $\mathrm{i}^{\text {th }}$ location. Mapping of predicted soil nutrients was performed using QGIS open source software version 3.8.

\subsection{Mapping of soil acidity status and lime recommendation}

The acidity status of the study area was prepared by using critical levels according to the EthioSIS project, proposed by MoA and EthioSIS team analysis (2014) (Figs. 8 and 12). For the area of strongly acidic with $\mathrm{pH} \leq 5.5$, agricultural lime was recommended based on acid saturation method (Eq. 2) as outlined by Farina and Channon (1991). The lime requirement (LR) factor of 1.160 was developed for Ethiopian conditions based on field trials conducted by using ag-lime. The permissible acid saturation of $10 \%$ was used for all crops (Taye 2008).

$L R=1160($ EA-ECEC*PAS) Eq. 2

Where: LR = Lime Recommended (ton/ha)

$1160=$ LR Factor

$\mathrm{EA}=$ Exchangeable Acidity $\left(\mathrm{cmol}_{+} / \mathrm{kg}\right)$

$\mathrm{ECEC}=$ Effective Cation Exchange Capacity $\left(\mathrm{cmol}_{+} / \mathrm{kg}\right)=\mathrm{Ca}+\mathrm{Mg}+\mathrm{K}+\mathrm{Al}+\mathrm{H}$

PAS = Permissible Acid Saturation

\subsection{Mapping of the basic cations}

The EthioSIS critical levels (Figs. 8 and 12) were used for soil fertility mapping. However, Manbir et al. (2015) indicated that, soil test $\mathrm{K}$ alone may not be adequate to predict $\mathrm{K}$ response. Plants produce higher yields at a certain Ca:Mg ratio and K:Mg ratio on acidic soils which are 10:1 and 0.7:1, respectively (Loide, 
2004). Noting that, for potash fertilizer application, $\mathrm{K}: \mathrm{Mg}$ ratio of $0.7: 1$ was used as a critical point, since the amount of $\mathrm{K}$ was low compared to $\mathrm{Mg}$ in the area.

\section{Results And Discussions}

\subsection{Physiography of the study area}

The physical landscape of Jimma Arjo is quite diversified. The major topographic features of the district are composed of hills, flat to undulating rugged topography, plain, plateau and valley with altitude ranging from 1280 m.a.s.I at Didessa valley floor in the south to 2564 meter above sea level (m.a.s.l.) at Hine ridge at the North western part of the district (Fig. 5).

\subsection{Soil properties and descriptive statistics}

The data set which was used for analysis consists of the following soil properties: $\mathrm{pH}, \mathrm{EA}$, exchangeable cations $\left(\mathrm{K}^{+}, \mathrm{Na}^{+}, \mathrm{Ca}^{++}, \mathrm{Mg}^{++}\right)($Table 1$)$.

Table 1

Descriptive statistics of soil properties analysed by PCA

\begin{tabular}{|c|c|c|c|c|c|c|c|c|}
\hline \multirow{2}{*}{$\begin{array}{l}\text { Soil } \\
\text { Properties }\end{array}$} & \multicolumn{8}{|c|}{ Statistics } \\
\hline & Min & Max & $\begin{array}{l}\text { 1st } \\
\text { Quartile }\end{array}$ & Median & $\begin{array}{l}\text { 3rd } \\
\text { Quartile }\end{array}$ & Mean & $\begin{array}{l}\text { Var. } \\
(n-1)\end{array}$ & $\begin{array}{l}\text { Std. dev } \\
(n-1)\end{array}$ \\
\hline $\mathrm{pH}$ & 4.450 & 6.8700 & 5.4800 & 5.8000 & 6.0100 & 5.7400 & 0.1600 & 0.4000 \\
\hline EA & 0.030 & 4.4300 & 0.0000 & 0.0000 & 0.1550 & 0.3800 & 0.7100 & 0.8400 \\
\hline $\mathrm{Ca}$ & 1.580 & 18.280 & 3.4800 & 5.0600 & 7.9100 & 6.3000 & 13.630 & 3.6900 \\
\hline $\mathrm{Mg}$ & 0.550 & 7.3100 & 1.1700 & 1.7100 & 2.9600 & 2.2500 & 2.3000 & 1.5100 \\
\hline K & 0.180 & 3.5900 & 0.5700 & 0.8500 & 1.2000 & 0.9500 & 0.2900 & 0.5400 \\
\hline $\mathrm{Na}$ & 0.080 & 0.4300 & 0.1100 & 0.1400 & 0.1700 & 0.1500 & 0.0040 & 0.0600 \\
\hline LR & 0.042 & 4.1000 & 0.5360 & 1.3860 & 2.2640 & 1.4650 & 0.0300 & 1.0590 \\
\hline $\begin{array}{l}n=\text { number } \\
\text { charge per } \\
\text { measured }\end{array}$ & $\begin{array}{l}\text { bserva } \\
\text { ram of } \\
\text { is per h }\end{array}$ & $\begin{array}{l}\text { n; Var }= \\
\text { il; LR = } \\
\text { tare. }\end{array}$ & $\begin{array}{l}\text { riance; } S \\
\text { ne rate; }\end{array}$ & $\begin{array}{l}\text { ev. }=\text { Sta } \\
\text { a, Mg, K, }\end{array}$ & $\begin{array}{l}\text { ard devi } \\
\text { a, were } n\end{array}$ & $\begin{array}{l}\text {; } \mathrm{cmol+} \\
\text { ured in }\end{array}$ & $\begin{array}{l}=\text { centi } \\
\mathrm{Ol}_{+} / \mathrm{kg} ;\end{array}$ & $\begin{array}{l}\text { oles of } \\
\text { was }\end{array}$ \\
\hline
\end{tabular}

The first result to look at is the correlation matrix, according to Pearson (n) (Table 2), pH was positively and significantly correlated with $\mathrm{EC}, \mathrm{K}, \mathrm{Ca}, \mathrm{Mg}, \mathrm{Na}$, and negatively correlated with $\mathrm{EA}$ and $\mathrm{Al}$. These relationships are discussed under each parameter. 
Table 2

Correlation matrix (Pearson) of the variables

\begin{tabular}{|c|c|c|c|c|c|c|c|}
\hline \multirow[t]{2}{*}{ Variables } & \multirow[t]{2}{*}{$\mathrm{pH}$} & \multirow[t]{2}{*}{ EC } & \multirow[t]{2}{*}{ EA } & $\mathrm{Ca}$ & $\mathbf{M g}$ & K & $\mathrm{Na}$ \\
\hline & & & & \multicolumn{4}{|c|}{ Exchangeable } \\
\hline $\mathrm{pH}$ & 1.00 & & & & & & \\
\hline EC & 0.21 ** & 1.00 & & & & & \\
\hline EA & $-0.62^{\star *}$ & $-0.09 n s$ & 1.00 & & & & \\
\hline $\mathrm{Ca}$ & $0.57 * \star$ & $0.29 * *$ & $-0.41 * \star$ & 1.00 & & & \\
\hline $\mathrm{Mg}$ & $0.50 * \star$ & $0.26 * *$ & -0.36 ** & $0.91^{* *}$ & 1.00 & & \\
\hline K & $0.28 * *$ & $0.30 * *$ & $-0.18^{*}$ & $0.15^{\star}$ & $0.13 \mathrm{~ns}$ & 1.00 & \\
\hline $\mathrm{Na}$ & $0.22^{\star \star}$ & $0.23 * *$ & $-0.19 * *$ & $0.79 * *$ & $0.74^{* *}$ & $-0.10 \mathrm{~ns}$ & 1.00 \\
\hline
\end{tabular}

As shown in Fig. 6 extracted from PCA, the score plot showed a continuous distribution of the points without grouping. This shows that the changes in soil properties in some observations are not very different from the ones in other observations. There is no big difference between the changes in soil properties across the district. In addition, it shows there was some outlier data recorded, for example sample number 185,186 and 168 . The first two samples were outliers with their phosphorus status and were removed.

The map of variables (Fig. 7) is useful in interpreting the relationship between variables. The PC-1 is not linked with any of the parameter while PC-2 is linked with $\mathrm{Al}, \mathrm{EA}, \mathrm{pH}, \mathrm{Ca}, \mathrm{Mg}, \mathrm{K}$ and $\mathrm{Na}$. It shows that $\mathrm{pH}$ is negatively correlated with $\mathrm{EA}$ and positively correlated with $\mathrm{Mg}, \mathrm{Ca}, \mathrm{Na}$, and $\mathrm{K}$.

\subsection{Soil pH and exchangeable acidity}

The $\mathrm{pH}$ of the area ranged from 4.45 to 6.87 (Table 1 and Fig. 8) and the minimum value was observed in the higher altitude of the area while the maximum value was observed in the lower altitude. The higher altitude areas of the district is highly populated which results in intensive agriculture, high biomass consumption for different purposes than leaving on farm, low temperature results in low biomass decomposition and no volatilization of basic cations from sub soil and favours leaching. All these processes result in decrease of $\mathrm{pH}$ value in the higher altitude areas of the district than the lower altitude areas (Shamsher et al., 2019). According to pH rating suggested by EthioSIS (2014) (Figs. 8 and 12), strongly acidic soils accounted for about $17.1 \%$ (13,125 ha), while moderately acidic soils accounted for about $78.4 \%$ (60,034 ha) of the total area of the district (Figs. 8 and 9). Most plant nutrients are fixed when the soil pH is less than 5.5. Phosphorus binds to different cations present in solution leaving less 
free phosphate ions for uptake by plants. On the other hand, most plant nutrients are optimally available at $\mathrm{pH}$ value greater than 5.5 and less than 7.5 which is also compatible to plant root growth (Cerozi and Fitzsimmons, 2016).

Since the district falls under high rainfall receiving area, there is leaching of bases and clay particles. As a result, the whole surface soils were categorized under acidic soils with $\mathrm{pH}$ value less than 7 . Habtamu et al. (2014) also indicated the same reason for the cause of soil acidity in the north western highlands of Ethiopia where all the studied agricultural soils were acidic, with $\mathrm{pH}$ between 4.45 and 5.00 . Most of the area of the district is covered with moderately acidic soils which do not need lime but only $17.1 \%$ of the soils need liming. Most of the areas (78.4\%) were covered with soils of $\mathrm{pH}$ value between 5.5-6.87 which were free from Aluminium toxicity and expected to be trouble free so that it does not require applications of lime.

Soil reaction or $\mathrm{pH}$ was significantly and positively correlated with $\mathrm{EC}, \mathrm{K}, \mathrm{Ca}, \mathrm{Mg}, \mathrm{Na}$, and significantly but negatively correlated with EA and Al (Table 2). Soil pH affects the bioavailability of plant nutrients and so crop plant growth (Goulding, 2016). Presence of exchangeable Aluminium in soil matrix removes basic cations from soil colloid and makes it leach down the soil profile. The presence of this free Aluminium also results in hydrolysis reaction which generates $\mathrm{H}^{+}$ions in the soil. These processes decrease the $\mathrm{pH}$ of the soil. In addition, low pH medium hinders the activity of beneficial soil microorganisms which decompose soil organic matter to replenish the basic cations through mineralization and maintain the nutrient balance.

The maximum exchangeable acidity is $4.43 \mathrm{cmol}+/ \mathrm{kg}$ while the minimum is $0.03 \mathrm{cmol}+/ \mathrm{kg}$ and the mean value was $1.46 \mathrm{cmol}+/ \mathrm{kg}$ for those soils with $\mathrm{pH}$ value $\leq 5.5$ (Table 1 and Fig. 8). In terms of exchangeable acid saturation, the district was categorized into three classes as optimum, high, and very high which accounted for $81.4,11.7$ and $2.4 \%$ respectively (Fig. 10).

\subsection{Exchangeable bases ( $\mathrm{Ca}, \mathrm{Mg}, \mathrm{K}$ and $\mathrm{Na}$ )}

Generally, the maximum value of total exchangeable bases (TEB) was $25.9 \mathrm{cmol}+/ \mathrm{kg}$ and recorded in the lowlands of the district and the minimum value was $3.11 \mathrm{cmol}+/ \mathrm{kg}$ and was recorded in the highlands (Table 1). In fact, this situation is the general trend of soil property since the salts accumulate at lowlands where runoff speed slows down. In undulating mountainous landscapes, soil erosion is a dominant driver of change (Hurni et al., 2015; Vanlauwe et al., 2015) and landscape variability results in nutrient variability. In addition, the hot temperature at lowlands has an impact on accumulation of salts on the surface soil. On the other hand, there was leaching of salts where there were high rainfall, low temperature, and intensive cultivation especially in acidic tropical soils (Gebeyehu, 2007).

According to the critical level suggested by EthioSIS (2014), almost the whole agricultural land of the area contained enough exchangeable $\mathrm{Ca}$ saturation for crop production. Therefore, the district does not require calcium application for crop production. However, addition of $\mathrm{Ca}$ in the form of lime was required to soils Loading [MathJax]/jax/output/CommonHTML/jax.js , more than permissible amount for acid soil reclamation. 
Habtamu et al. (2014) also reported that the amount of exchangeable bases were sufficient for crop production in north western highlands of Ethiopia.

Exchangeable Mg saturation status for the entire district was above optimum level for crop production. Compared to the lowlands, the minimum amount of $\mathrm{Mg}$ was recorded at highlands of the district which might be the consequence of low $\mathrm{pH}$, since $\mathrm{Mg}$ was significantly and positively correlated with $\mathrm{pH}(\mathrm{r}=0.5)$ (Table 2). He et al. (1999) reported that the lowest exchangeable Mg was obtained in cultivated land which could be due to the high intensity of cultivation and abundant crop harvest with little or no use of inputs. Therefore, low $\mathrm{pH}$, high intensity of cultivation and total biomass harvest might be the reason for lowering Mg content of the highland. On the contrary, according to the ratings set by Eckert (1987), only $10 \%$ of the total soils collected contain balanced Ca:Mg ratio and the other $90 \%$ were categorized under low Ca status. This difference may be due to the use of different extraction method during the critical level setting and this needs to be checked by field trials giving due attention to extraction method.

Potassium content of most soils of the district was categorized under optimum according to EthioSIS critical levels (2014) and constitutes $91.69 \%$ of the total area of the district. The other areas that constitute $3.86 \%$ of the total area were categorized under low content of exchangeable K. According to the $\mathrm{K}: \mathrm{Mg}$ ratio, the result of this study showed that $74.83 \%$ of the total area required $\mathrm{K}$ fertilizer application. In the Ethiopian history, farmers in the area did not use $\mathrm{K}$ fertilizer, which indicates that $\mathrm{K}$ is being depleted from the area and care should be taken regarding $\mathrm{K}$ management.

Sodium content of the district was expressed by exchangeable sodium percentage (ESP). According to EthioSIS critical level (2014), most of the area contained ESP below optimum level and 90.9 and $4.5 \%$ of the total area of the district were categorized under low and very low status, respectively, while only $0.1 \%$ were above the critical level. Therefore, there is no soil problems related to sodium, like alkalinity, sodicity or soil particle dispersion.

Murphy and Hazelton (2007), suggested different ways of expressing exchangeable cations as more relevant indicator to plant performance than the actual level. They suggested the proportion of ECEC occupied by the basic cations. According to this rating, Ca was relatively at more desirable proportion which accounted for $45.3 \%$ of the total samples collected and the others $4.1,17.2$ and $6.25 \%$ were for $\mathrm{Mg}$, $\mathrm{K}$ and $\mathrm{Na}$, respectively which were at desirable proportion.

The cation exchange sites of the soils were dominated by $\mathrm{Ca}$ among the exchangeable bases. The order of abundance was $\mathrm{Ca}>\mathrm{Mg}>\mathrm{K}>\mathrm{Na}$ (Table 1 and Fig. 11). This is the general trend for non-saline and non-sodic soils since divalent cations are preferred than monovalent ones by cation exchange sites. This result is also the same with the findings of different authors (Lar, 2014, Teferi, 2008 and F.Tesfay et al.,2020).

\subsection{Recommendations}


Lime rate recommendation was generated for every sampled area according to acid saturation method of LR rate calculation (Eq. 1) and then predicted for non-sampled areas by kriging. About $17.78 \%$ of the total area of the district required lime (Fig. 12). The minimum and maximum value of the lime rate were 0.042 and 4.10 tons/ha, respectively (Table 1). Most of the area of the district, which covers $77.62 \%$ of the total area, did not require lime. From the total area of the district, $12.63 \%, 4.36 \%$, and $0.88 \%$ require lime at a rate of less than $1,1-2$ and $2-4.1$ tons/ha, respectively.

As it can be seen from the LR map of the district (Fig. 12) higher lime rate is required for highland areas of the district and outward expansion of soil acidity status was observed. This indicates that the surrounding soils will gradually become acidic in the near future.

\subsubsection{Other Recommendations}

To clearly understand the productivity of the soils of the district, testing other chemical, physical and biological parameters of the soils and recommending relevant intervention is very important. The physical parameters may include water holding capacity, permeability, drainage, tillage, soil structure and recommendation of proper soil and water conservation practices in the district. The chemical parameters may include other essential plant nutrient status, nutrient balance, and targeting the right source and rate of fertilizer is also very important. The biological parameters may include recommendation of proper biofertilizers, other beneficial soil microorganisms, and biological soil and water conservation practices. In the study at Tigray, Ethiopia, Corbeels et al. (2000), also indicated that farmers' perceptions of soil fertility are not limited to the soils' nutrient status, it also includes all soil factors affecting plant growth.

Effective lime rate recommendation method needs to be selected and used in the country, because different region uses different recommendation method. In addition, the prediction of soil parameters at non sampled areas needs to be updated to regressional kriging which uses as much of the variables dictating the nutrient status of an area in order to increase the accuracy of nutrient prediction for nonsampled areas. Soil physical and biological conservation measures need to be encouraged in the district.

Lime rate determination is not only depending on soil test results. Because, there are different environmental factors that influence the magnitude of crop response to the applied lime. Therefore, field experiment is required to accurately detect the response of crops to applied lime and recommend the right amount of lime for specific area. In addition, soil fertility surveillance is needed to periodically assess the acidity status and deficient nutrients across the district.

\section{Conclusions}

The highland areas of the district were more populated than the lowlands (personal observation). As a result, there is more adverse impact on the soils of the highland which includes intensive agriculture and free grazing resulting in soil acidity. In addition, the high rainfall and relatively cooler temperature may also result in the acidity of the highlands. The magnitude and extent of soil acidity in the area is

Loading [MathJax]/jax/output/CommonHTML/jax.js n entry point to mitigate further expansion. The key challenge 
prevented the farmers from using lime is lack of policy to include lime into agricultural input value chain. The observed dependency of the soil acidity on landscape position could be a proxy indicator of the difference in fertility status of the two landscapes.

The main bottlenecks for soil fertility decline in the area were: soil acidity, deficient nutrients, lack of soil conservation, and total removal of crop residues from the field, fertilizer use system and low awareness of farmers on the use of integrated soil fertility management.

\section{Abbreviations}

\begin{tabular}{|ll|}
\hline CSA & Central Statistical Agency \\
\hline CSA-LCCS & Central Statistical Agency-Land Cover Classification Survey \\
\hline EA & Exchangeable Acidity \\
\hline EC & Electrical Conductivity \\
\hline ECEC & Effective Cation Exchange Capacity \\
\hline ESP & Exchangeable Sodium Percentage \\
\hline EthioSIS & Ethiopian Soil Information System \\
\hline GDP & Gross Domestic Product \\
\hline GPS & Geographical Information System \\
\hline ha & Global Positioning System \\
\hline IR & Hectare \\
\hline LR & LR \\
\hline m.a.s.I & Meter above sea level \\
\hline MoA & Ministry of Agriculture \\
\hline
\end{tabular}

\section{Declarations}

\section{Ethics approval and consent to participate}

Not applicable

\section{Consent for Publication}

Not applicable 
Availability of data and materials

The datasets used and/or analyzed during the current study are available from the corresponding author on reasonable request

All data generated or analysed during this study are included in this published article

\section{Funding}

Not applicable

\section{Competing interests}

The authors declare that they have no competing interests

\section{Author's contributions}

Fayisa Olana collected all the raw data from the field, organized, analysed and drafted this article. Doctor Hailu Shiferaw, as an advisor, provided indispensable encouragements, comments, suggestions, and scholastic guidance.

\section{Acknowledgments}

I would like to acknowledge Oromia Agricultural Research Institute and Ethiopian Agricultural Transformation Agency for supporting through allocating budget for data collection.

\section{References}

1. Agegnehu G, Amede T (2017) Integrated soil fertility and plant nutrient management in tropical agroecosystems: a review. Pedosphere 27:662-680

2. Amede T, Gashaw T, Legesse G, Tamene L, Mekonen K, Thorne Pand Schultz S (2020) Landscape positions dictating crop fertilizer responses in wheat-based farming systems of East African Highlands. Renewable Agric Food Syst. 1-13. https://doi.org/10.1017/S1742170519000504

3. Cerozi B, Fitzsimmons K (2016) The effect of pH on phosphorus availability and speciation in an aquaponics nutrient solution. Biores Technol 219:778-781. 10.1016/j.biortech.2016.08.079

4. Corbeels M, Abebe Shiferaw and Mitiku Haile (2000) Farmers' knowledge of soil fertility and local management strategies in Tigray, Ethiopia. Managing Africa's soil, No. 10 IIED, London

5. Central Statistical Agency (2019) /20) Agricultural Sample Survey, volume I: Report on Area and Production of major Crops, Private Peasant Holdings, Meher Season. Addis Ababa, Ethiopia

6. Eckert DJ (1987) Soil test interpretations: basic cation saturation ratios and sufficiency levels. In: Brown JR (ed) Soil testing: sampling, correlation, calibration, and interpretation. Spec. Publ. No. 21. Soil Science Society of America (SSSA), Madison, pp 53-64 
7. Farina M, Channon P (1991) A Field Comparison of LR Indices for Maize. Plant Soil Journal 134:127-135

8. Tesfay F, Kibret K, Gebrekirstos A, Meles Hadigu K (2020) Changes in selected soil properties across a chronosequence of exclosures in the central dry lowlands of Ethiopia. Eurasian J Soil Sci 2020, 9 (2) 173-185

9. Gebeyehu T (2007) Soil Fertility Status as Influenced by Different Land Uses in Maybar Areas of South Wello zone, North Ethiopia. Thesis, Haramaya University

10. Habtamu A, Heluf G, Bobe B, Enyew A (2014) Fertility Status of Soils under Different Land uses at Wujiraba Watershed, North-Western Highlands of Ethiopia. Agriculture, Forestry and Fisheries. 3 (5):410-419. doi: 10.11648/j.aff.20140305.24

11. He ZL, Alva AK, Calvert DV, Li YC, Banks DJ (1999) Effects of nitrogen fertilization of grapefruit trees on soil acidification and nutrient availability in Riviera fine sand. Plant Soil 206:11-19

12. HengI T, Leenaars JGB, Shepherd KD, Walsh MG, Heuvelink GBM, Mamo T, Tilahun H, Berkhout E, Cooper M, Fegraus E, Wheeler I, Kwabena NA (2017) Soil nutrient maps of Sub-Saharan Africa: assessment of soil nutrient content at $250 \mathrm{~m}$ spatial resolution using machine learning. Nutr Cycl Agroecosyst 109:107-102

13. Hurni K, Zeleke G, Kassie M, Tegegne B, Kassawmar T, Teferi E, Moges A, Tadesse D, Ahmed M, Kebebew Z, Hodel E, Amdihun A, Mekuriaw A, Debele B, Deichert G, Hurni H (2015) Economics of land degradation, Ethiopia case study. In: Soil degradation and sustainable land management in the rainfed agricultural areas of Ethiopia: An assessment of the economic implications. Report of the Economics of land Degradation Initiative, 94pp

14. International Food Policy Research Institute (2010) Fertilizer and Soil Fertility Potential in Ethiopia. Washington DC, USA

15. Kassaye Gurebiyaw and Abay Gelanew (2019) Soil degradation extent and dynamics of soil fertility improvement technologies in Majete Watershed, North Ethiopia. Journal of Soil Science Environmental Management 10(3):39-45

16. K W T Goulding (2016) Soil Use Management 32(3):390-399

17. Loid V (2004) About the effect of the contents and ratios of soil's available Calcium, Magnesium and potassium in liming of acid soils. Agronomy Research 2(1):71-82

18. Manbir K, Rakkar DW, Franzen A Chatterjee (2015) Evaluation of Soil Potassium Test to Improve Fertilizer Recommendations for Corn. Open Journal of Soil Science 5: 110-122. http://www.scirp.org/journal/ojsshttp://dx.doi.org/10.4236/ojss.2015.55011

19. Ministry of Agriculture, Regional Land Management and World Agro forestry Center (2005) Managing Land: A Practical Guidebook for Development agents in Ethiopia. AG Printing and Publishing Ltd, Kenya, pp 2-14, pp 106-158

20. Mulata E (2009) Land Use/Land Cover Dynamics and Soil Degradation Assessment Using Remote Sensing and GIS: A Case Study of Jima Arjo District (Western Ethiopia). MSc Thesis, Addis Ababa 
21. Murphy B, Hazelton P (2007) Interpreting Soil Test Results: What Do All the Numbers Mean? CSIRO Publishing, Collingwood, Australia. 152p

22. Shamsher Ali, Hussain I, Hussain S (2019) Effect of Altitude on Forest Soil Properties at Northern Karakoram. Eurasian Soil Sc 52:1159-1169. https://doi.org/10.1134/S1064229319100120

23. Taye Bekele (2008) Estimation of Lime Recommendation. Training manual for regional soil testing laboratory heads and technicians. National Soil Testing Center, Ministry of Agriculture, Addis Ababa, Ethiopia

24. Vanlauwe B, Descheemaeker K, Giller KE, Huising J, Merckx R, Nziguheba G, Wendt J, Zingore S (2015) Integrated soil fertility management in sub-Saharan Africa: unravelling local adaptation. SOIL 1:491-508

25. World Food Programme (2017) WFP East and Central Africa Horn of Africa Drought Crisis Situation Report \#3, 15. http://reliefweb.int/report/ somalia/wfp-east-central-africa-horn- africa-drought-crisissituation-report3-15-march-2017 (Accessed 22 December 2019)

\section{Figures}

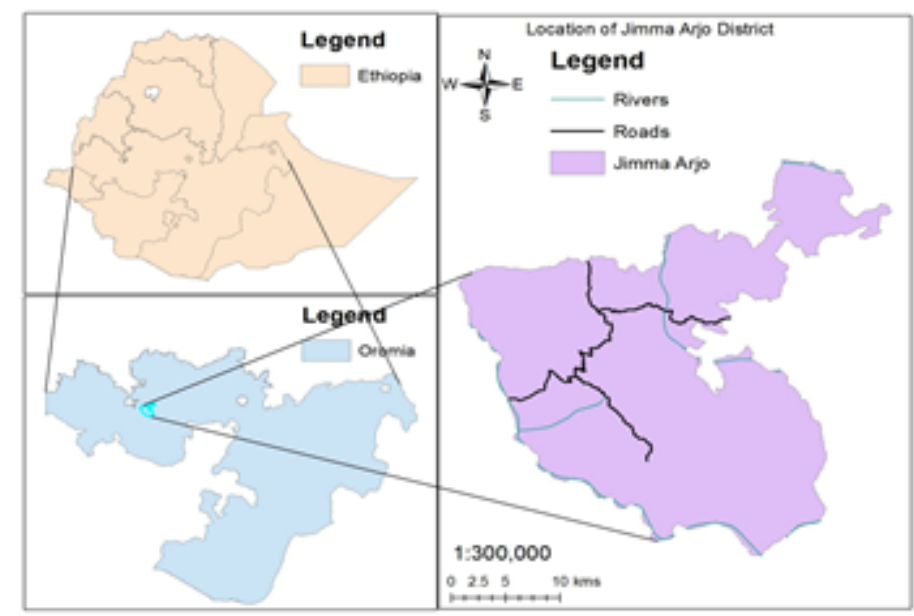

Figure 1

Location map of the study area.

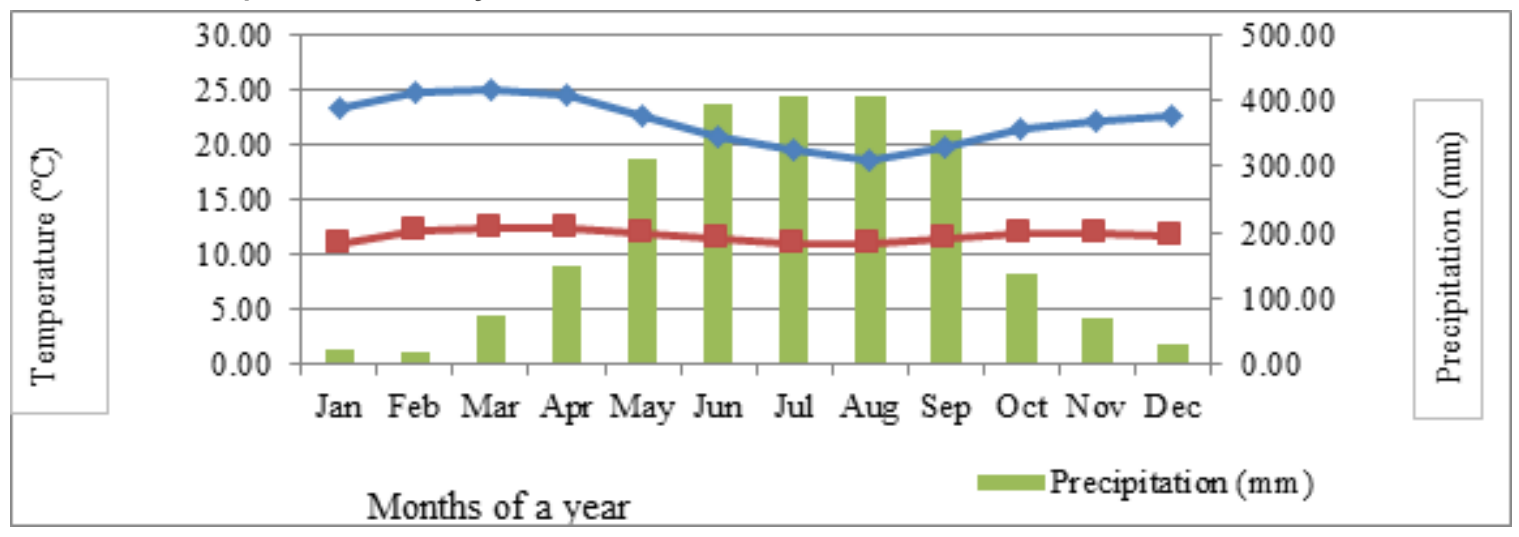


Figure 2

The ten years (2004-2014) meteorological data.

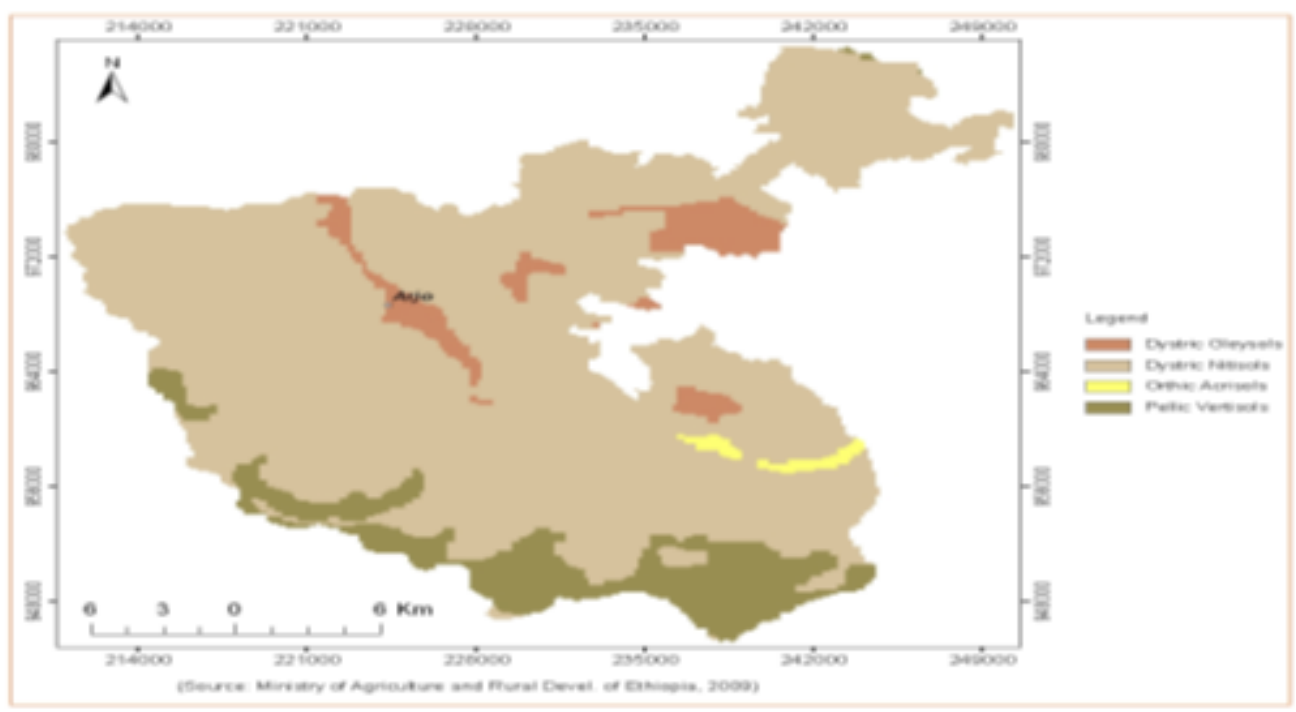

\section{Figure 3}

Major soil orders of Jimma Arjo district (source: MOA, 2009)..

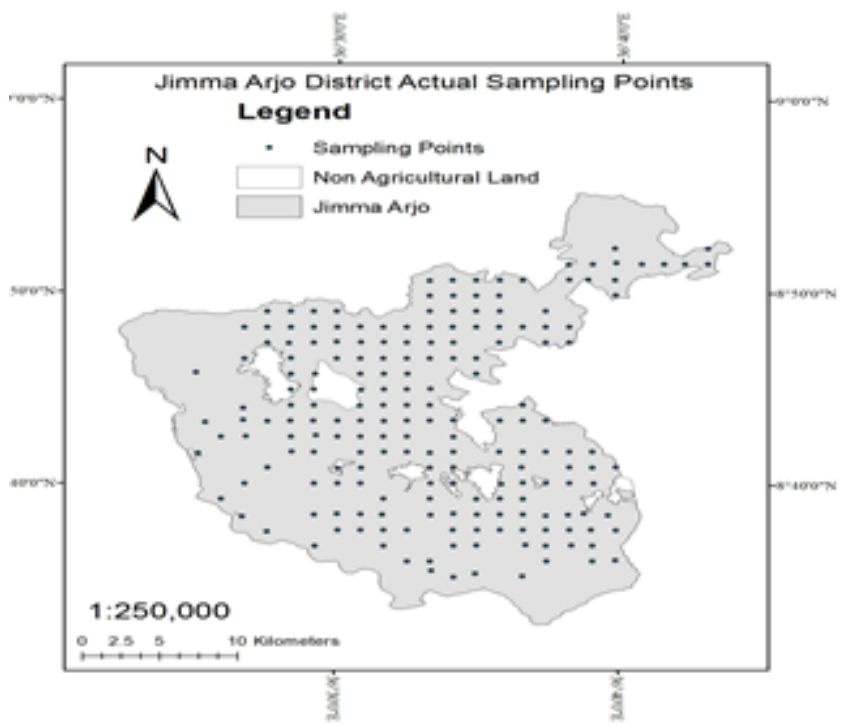

\section{Figure 4}

The actual sampling location of Jimma Arjo district. 


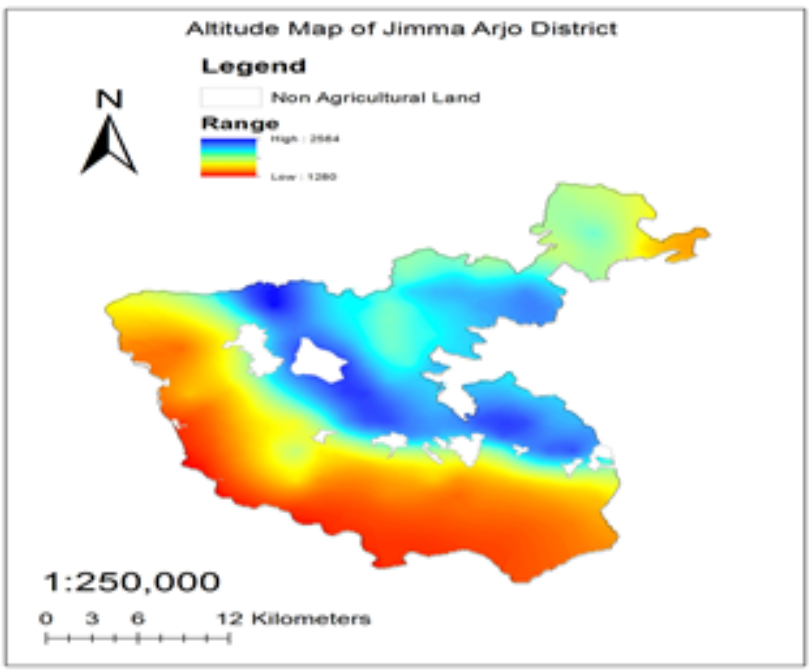

\section{Figure 5}

Altitude map of Jimma Arjo district, Ethiopia

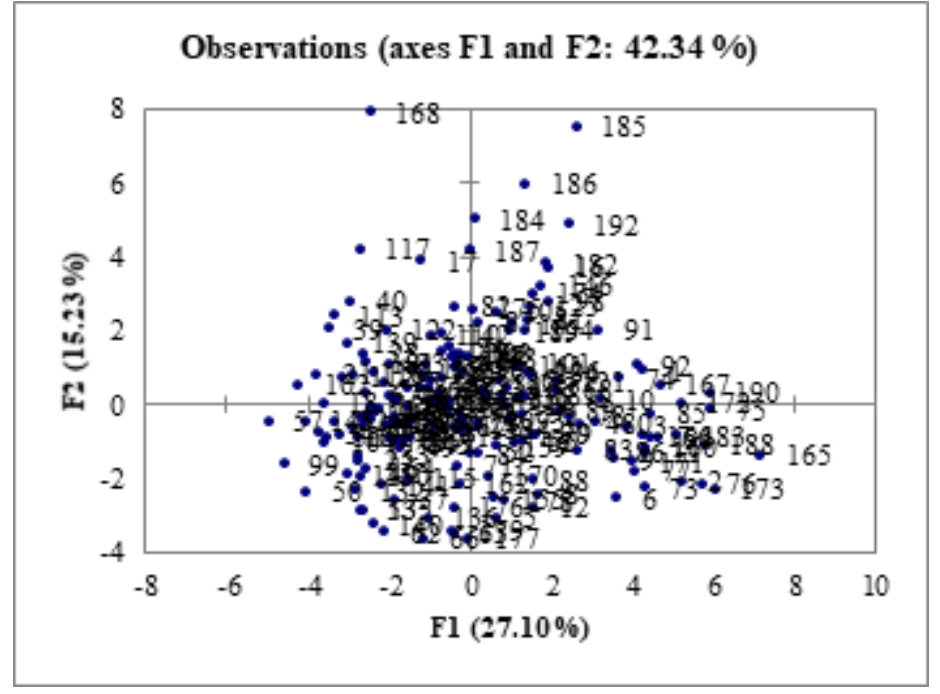

Figure 6

Map of samples (score plot) showing the relationships between observations for soil properties collected across Jimma Arjo district. 


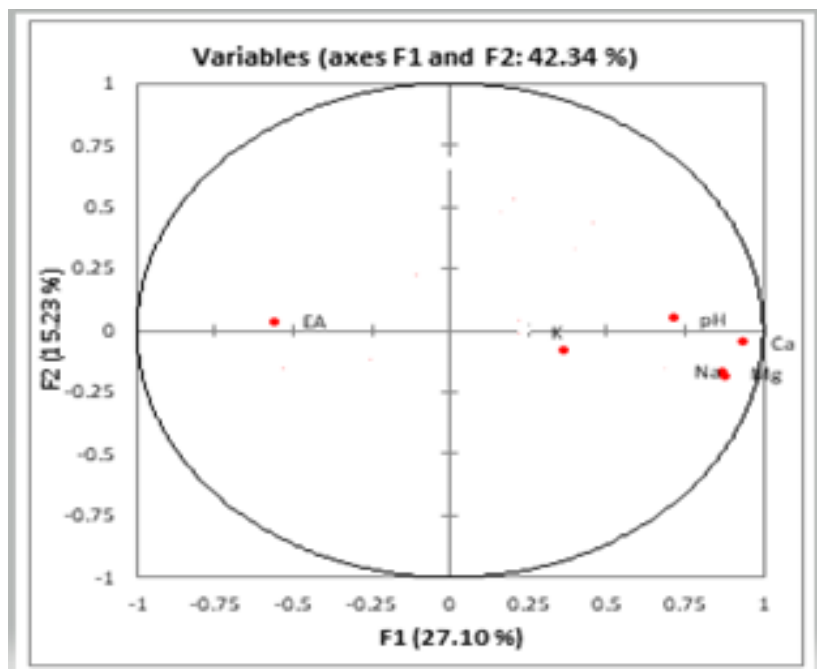

Figure 7

Map of variables (Correlation circle or loading plot) showing the relationship between variable.

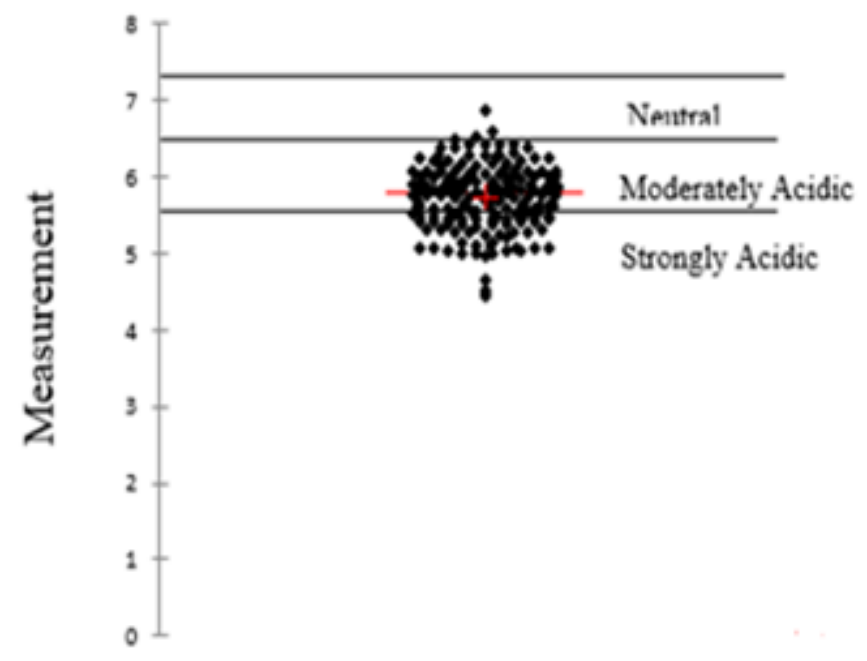

$\mathrm{pH}$

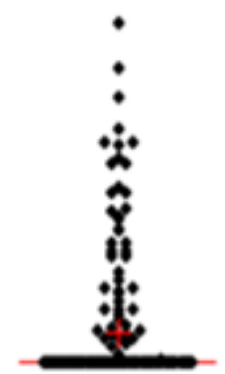

$\mathrm{EA}(\mathrm{cmol} / \mathrm{kg})$

\section{Figure 8}

Descriptive statistics and critical values adopted by EthioSIS of pH and EA. The horizontal line shows the median and the cross shows the mean. 

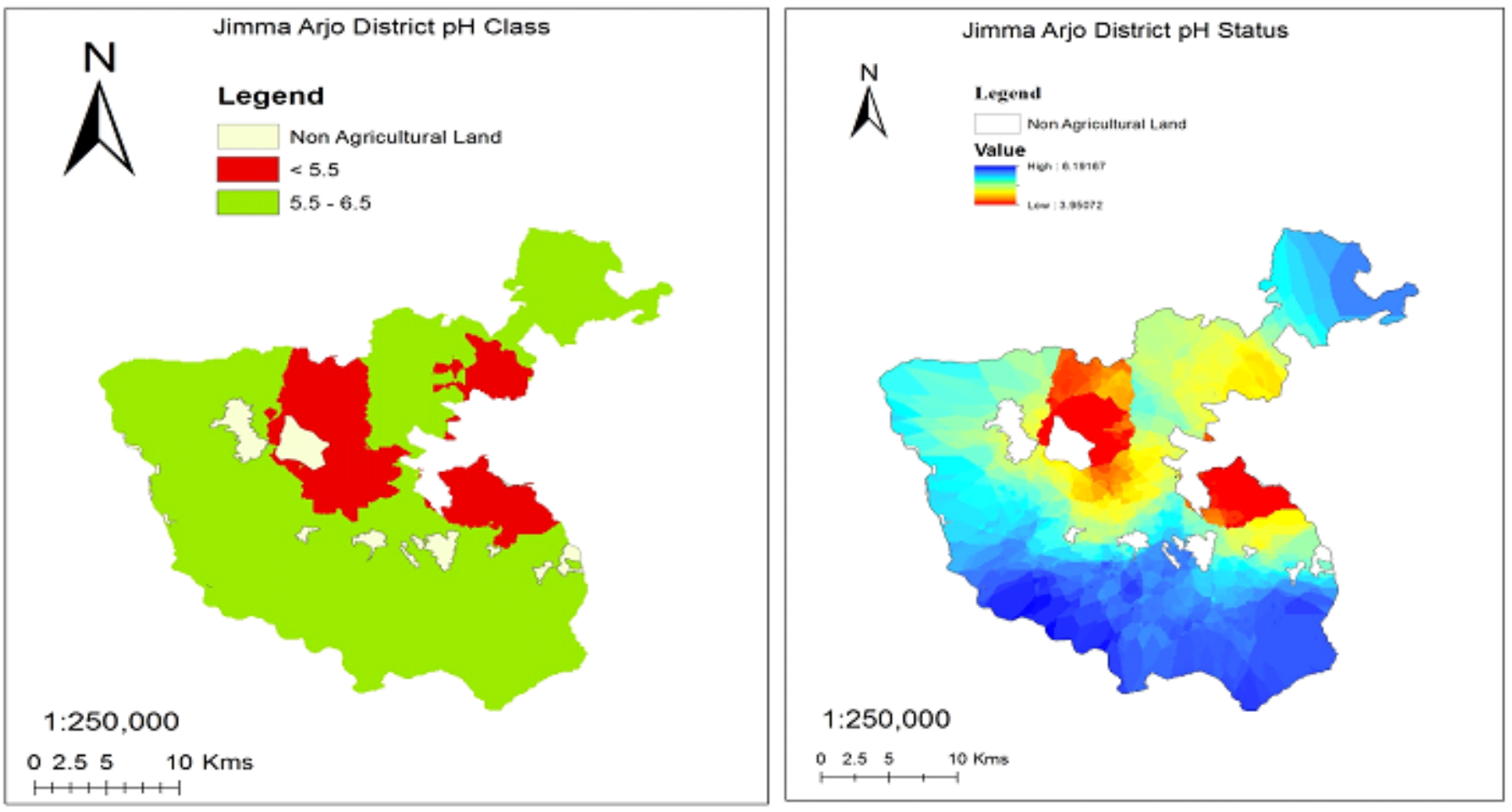

Figure 9

A map showing pH classes (left) and status (right).
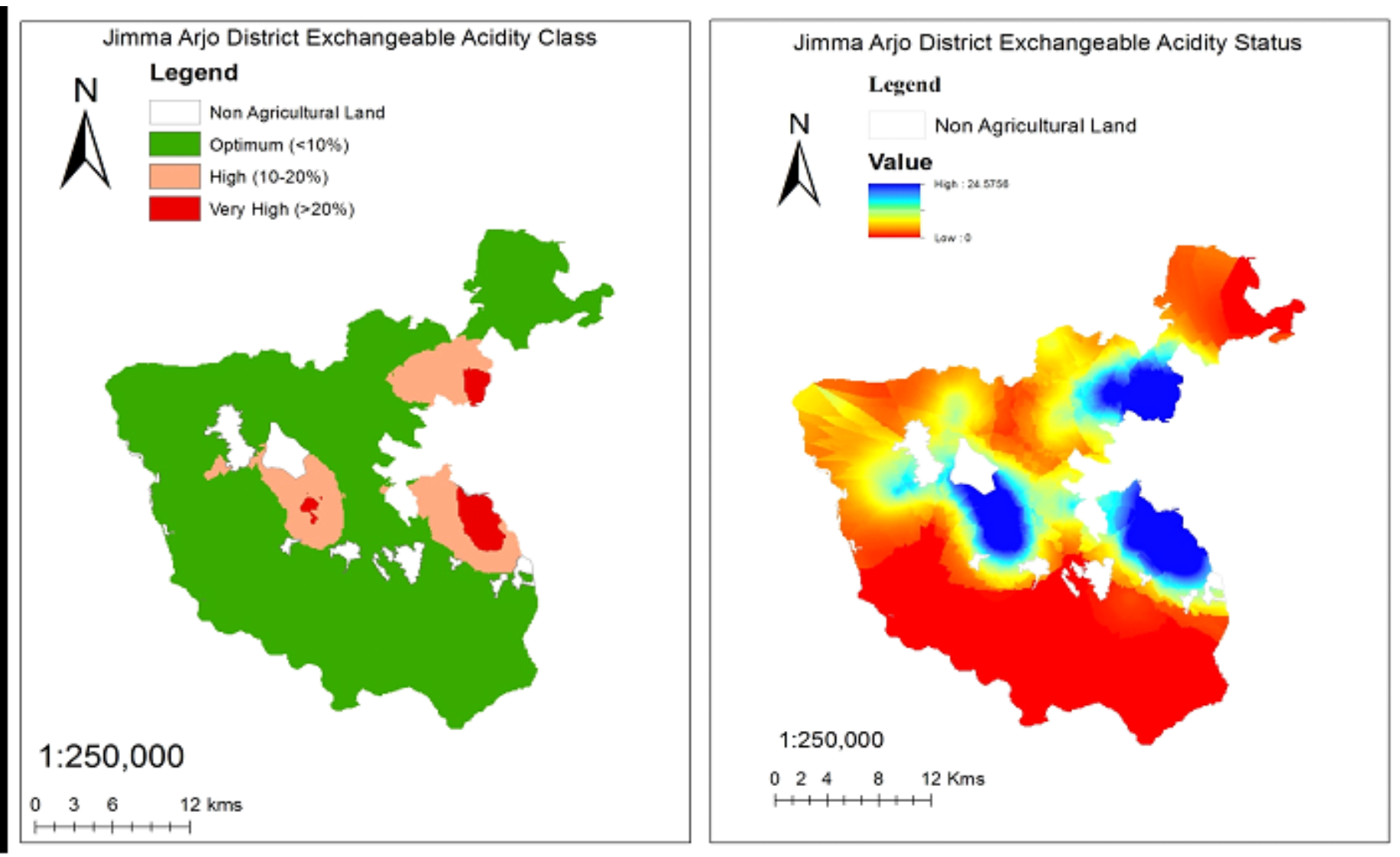

\section{Fiqure 10}

Loading [MathJax]/jax/output/CommonHTML/jax.js 
A map showing Exchangeable Acid Saturation (EAS) classes (left) and status (right).

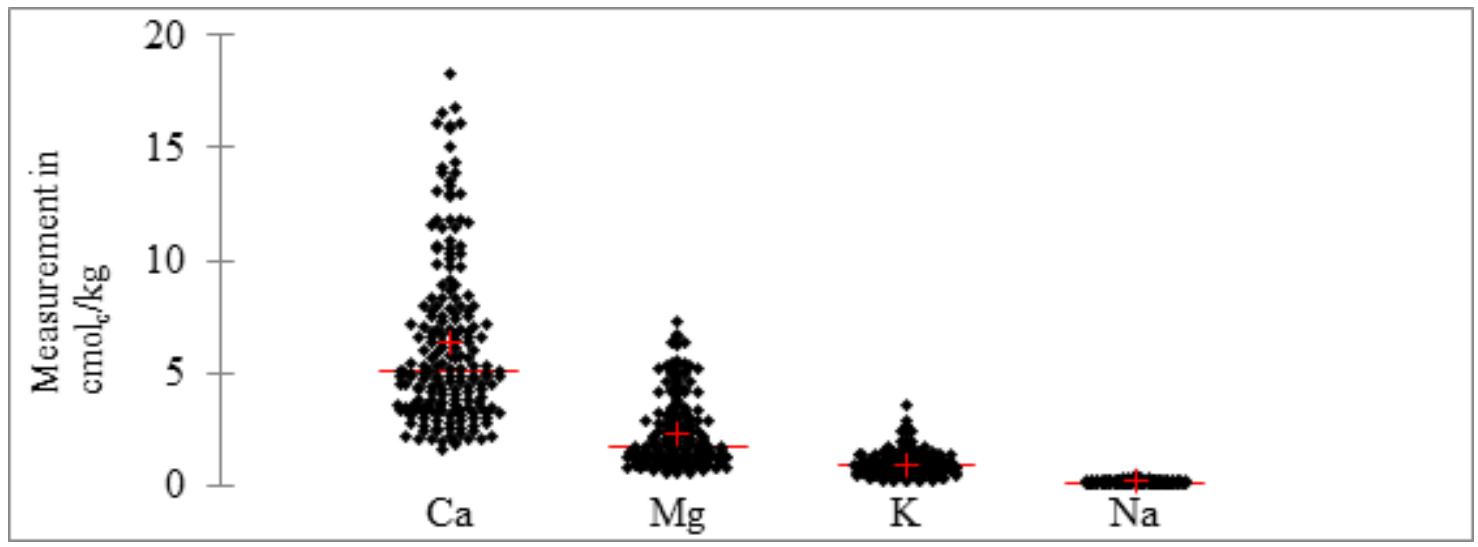

\section{Figure 11}

A univariate plot which shows descriptive statistics of exchangeable bases. The horizontal line represents median and the cross represents mean.
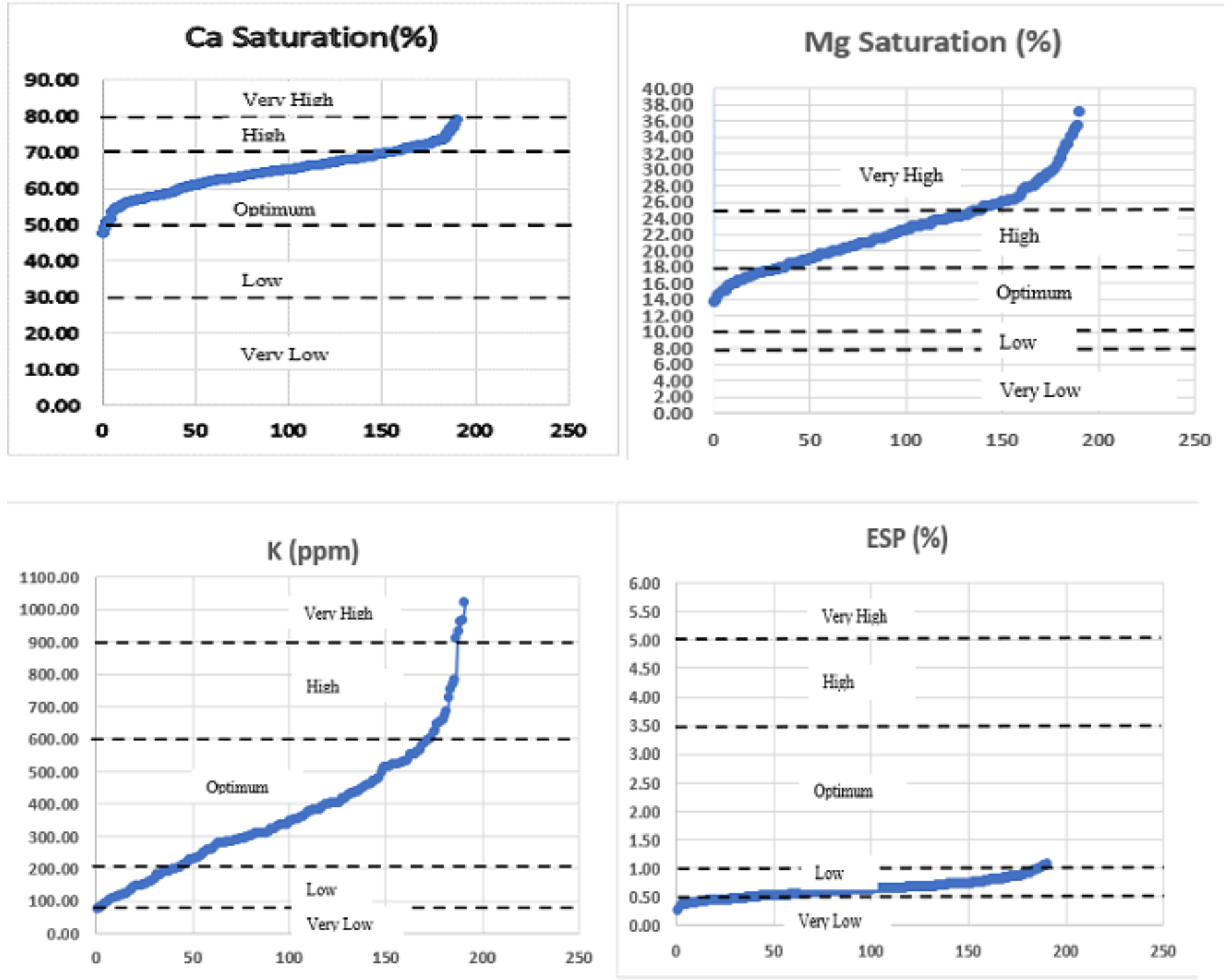
Figure 12

Critical values adopted by EthioSIS project and the actual values of basic cations in the study area.

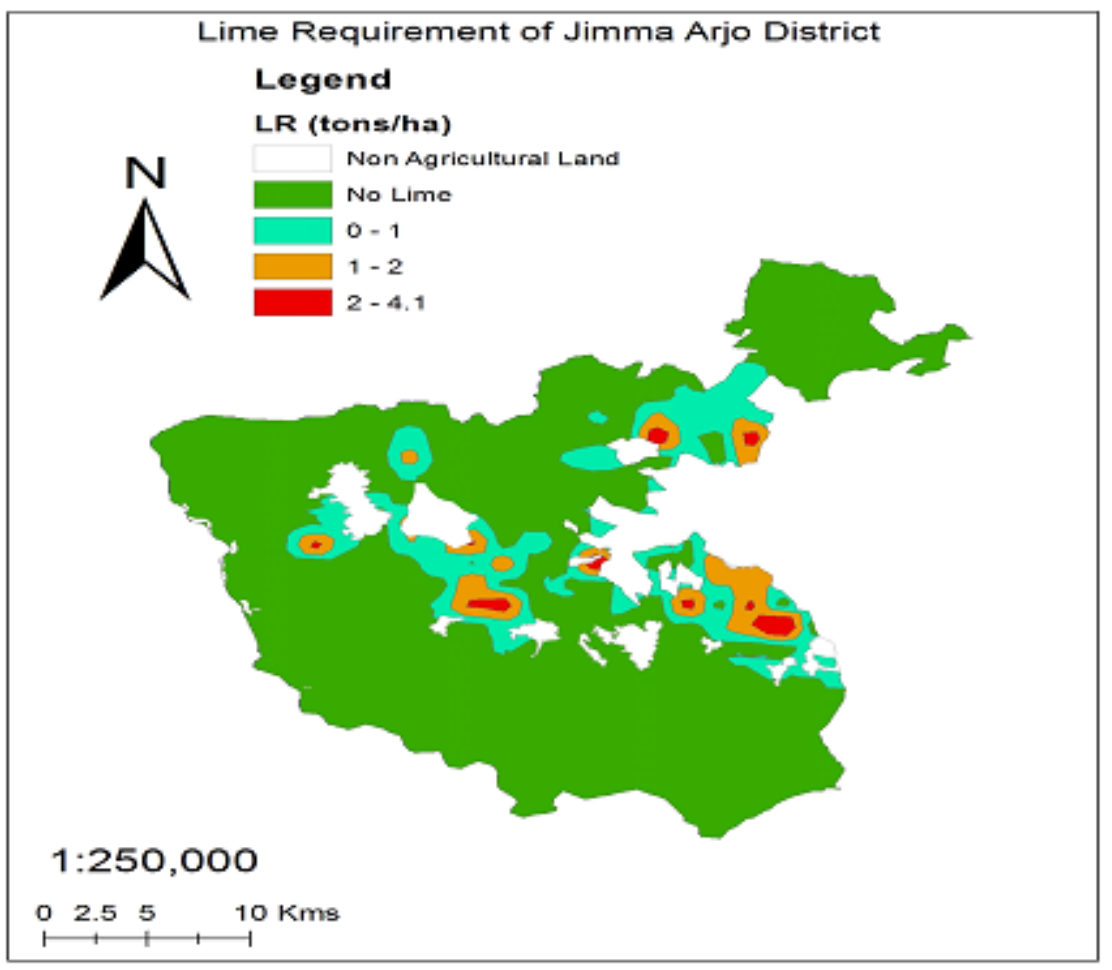

Figure 13

A map showing LR status. 